\title{
Early drain fluid amylase is useful to predict pancreatic fistula after pancreatoduodenectomy: lessons learned from a Southern Brazilian Center
}

\author{
Uirá Fernandes TEIXEIRA, Pablo Duarte RODRIGUES, Marcos Bertozzi GOLDONI, José Artur SAMPAIO, \\ Paulo Roberto Ott FONTES and Fábio Luiz WAECHTER
}

Received 3/1/2018

Accepted 6/2/2018

\begin{abstract}
Background - Pancreatic fistula represents the most feared complication after pancreatoduodenectomies, being the major responsible for the high morbidity and mortality after this operation. Its incidence remains around $10 \%$ to $30 \%$. In recent years, several authors have studied the value of amylase in abdominal drains fluid, measured at an early stage after the surgical procedure, as a useful tool to identify patients at risk of developing pancreatic fistula. Objective - To analyze the value of early drain fluid amylase as a method to predict the occurrence and severity of postoperative pancreatic fistula in patients undergoing pancreatoduodenectomies. Methods - We evaluated 102 prospective patients submitted to pancreatoduodenectomies from January 2013 to June 2017. The mensuration of amylase in abdominal drains was performed on days 1, 3, 5 and 7 in all patients. Patients were divided into three groups according to postoperative day 1 (POD1) results: values $<270 \mathrm{U} / \mathrm{L}$ (group 1); between 271 and 5.000 U/L (group 2); and values $>5.000 \mathrm{U} / \mathrm{L}$ (group 3). Results - The incidence of pancreatic fistula was $25.5 \%$, being 3.33\%, $27.3 \%$ and $41.02 \%$ in the three groups, respectively. Compared with group 1, the risk of developing pancreatic fistula increased with increasing amylase values on POD1. Amylase values on POD1 and POD3 of patients with pancreatic fistula were higher than in the other ones without this complication $(P<0.001)$. In addition, in group $3,37.5 \%$ of patients with pancreatic fistula evolved to death $(P<0.001)$. Finally, in this group, patients who died had drain fluid amylase values on POD1 significantly higher than the others in the same group $(P<0.001)$. Conclusion - Early drain fluid amylase value is a useful test to stratify patients in relation to the risk of developing pancreatic fistula after pancreatoduodenectomies, in addition to correlate with the severity of this complication.

HEADINGS - Pancreaticoduodenectomy. Amylases. Pancreatic fistula.
\end{abstract}

\section{INTRODUCTION}

Pancreatoduodenectomy (PD) still represents a challenging operation. Despite a significant decrease in the mortality rate after pancreatic head surgery, observed in centers of excellence in the last few years, morbidity rate did not follow this reduction, being in a steady state of about $40 \%-60 \%{ }^{(1)}$. The most feared complication that supplies these statistics is pancreatic fistula $(\mathrm{PF})^{(2)}$.

The fistula from the pancreatic stump anastomosis after PD deserves so much concern not only because of the increase in the morbi-mortality rate when it occurs, but also for the cost and need for resources to treat the affected patients. Therefore, efforts to identify earlier in the postoperative course patients that are prone to develop this complication is of utmost importance, as it is possible to select those that can be managed in enhanced recovery pathways ${ }^{(3)}$.

Amylase obtained in the first postoperative day (POD1), on drains fluid, emerges as an early tool to predict the occurrence and severity of pancreatic fistula after PD, as reports recent scientific evidence ${ }^{(4)}$. This test enables the stratification of patients in low-risk and high-risk ones, and also helps in decision-making regarding the management of prophylactic abdominal drains after that operation ${ }^{(5)}$.

Despite extensive literature throughout the world, there are no papers dealing with this issue in Brazil, although population studies report a large number of pancreatic surgery performed every year in the largest and most populous country in Latin America ${ }^{(6)}$. A significant number of patients and care providers may benefit from the information obtained after the results of drains fluid amylase.

Thus, these article aims to report the experience of a Brazilian tertiary Center after the implementation of routine mensuration of amylase on the liquid of abdominal drains after pancreatoduodenectomies. The objective is to evaluate the relation between POD1 amylase and the occurrence of pancreatic fistula. In addition, to understand the behavior of amylase values in the first days of these patients in an always-drainers team, and its usefulness in predicting the severity of this complication.

\section{METHODS}

Mensuration of amylase in the fluid of abdominal drains after PD started in 2013 in the Hepatobiliary and Pancreatic Surgical Division of Santa Casa Hospital of Porto Alegre / Federal University of Health Sciences of Porto Alegre, RS, Brazil. Since then and until June 2017, 128 patients underwent pancreatoduodenectomy in our Institution. The established protocol is to obtain amylase on drains fluid on POD1 (24 hours after the end of the operation), 3,5 and 7 and thenceforth as required. 
Until September 2016, drains were managed according to surgeon's discretion, even if they had low amylase levels on fluid. Most remain in place for at least 10 days. After that period, some patients that had low amylase values on drain's liquid on POD1 had drains removed on POD3, if they were evolving well, without any clinical consideration or changes in the aspect of the fluid.

This work represents a retrospective analysis of medical records, available at the Institution's database. Of the whole population, 26 patients were excluded because of incomplete data, remaining 102 for analysis. Patients were subdivided according to amylase values. Group 1, those with values $<270$ U/L (three times de upper serum amylase level at our Institution - which is the propose value to identify pancreatic fistula according to literature) $)^{(7)}$; group 2 represents values between 271 and 5.000 U/L (the latter being the most applied value to characterize low and high-risk patients); and group 3>5.000 U/L.

Pancreatic fistula was defined and graded according to the 2016 update of the International Study Group of Pancreatic Fistula (ISGPF) ${ }^{(7)}$. All the patients underwent gastric-preserving pancreatoduodenectomy with Child reconstruction, with two prophylactic drains placed at the end of the surgery: the first near biliary anastomosis and the second one watching over the pancreatojejunostomy.

Data were analyzed in SPSS version 22.0.0 through the chisquare test of homogeneity and Mann-Whitney test. A level of significance of $5 \%$ was used.

\section{RESULTS}

Demographics and main results are shown in TABLE 1. In this series, $58 \%$ of patients were male and $42 \%$ females, with the mean age of 63 years old. $58 \%$ of patients were operated on for ductal adenocarcinoma. TABLE 2 reports the main characteristics of pathology specimen.

TABLE 1. Characteristics of the patients and main results.

\begin{tabular}{lccc}
\hline & $\begin{array}{c}\text { Amylase } \\
<270 \text { U/L } \\
(30)\end{array}$ & $\begin{array}{c}\text { Amylase } \\
271-5.000 \\
\text { U/L (33) }\end{array}$ & $\begin{array}{c}\text { Amylase } \\
>5.000 ~ U / L \\
(39)\end{array}$
\end{tabular}

TABLE 2. Characteristics of the surgical specimen.

\begin{tabular}{lc}
\hline Pathology Report & Results \\
\hline Pancreatic AdenoCA & $58 \%$ \\
Ampullary AdenoCA & $21 \%$ \\
Cronic Pancreatitis & $6 \%$ \\
Neuroendocrine TU & $4 \%$ \\
Other & $11 \%$ \\
\hline
\end{tabular}

The mean POD1 and POD3 drain fluid amylase (DFA) were $3.561 \mathrm{U} / \mathrm{L}$ and $1.568 \mathrm{U} / \mathrm{L}$, respectively. The median values in the first evaluation (POD1) were significantly higher than in the third evaluation (POD3) in the three groups. Distribution of patients revealed that $30(29.4 \%)$ were in group $1,33(32.4 \%)$ and $39(38.2 \%)$ in groups 2 and 3 , respectively.

The pancreatic fistula rate in this series was $25.5 \%$ (26 patients), being $3.3 \%(1) ; 27.3 \%$ (9) and $41.02 \%$ (16) in groups 1 , 2 and 3, respectively. According to 2016 ISGPF Update, it was $18.6 \%$ (19) grade B and 6.9\% (7) grade C. Mortality rate was 7\%. Compared with group 1, the pancreatic fistula risk increased with the grown in DFA values on POD1: it was 6.4 higher in group 2 and 9.2 in group 3.

In comparative analysis, it was observed that those patients who developed pancreatic fistula presented higher median values of amylase in abdominal drains in the measurements of POD1 (7.608U/L x 706U/L, $P<0.001)$ and POD3 (1.885U/L x 184U/L; $P<0.001)$ - TABLE 3 . In addition, in G3, $37.5 \%$ of patients that developed pancreatic fistula evolved to death. Moreover, in this group, patients who died had POD1 amylase values significantly higher than the others in the same group $(17.777 \mathrm{U} / \mathrm{L} \times 6.002 \mathrm{U} / \mathrm{L}$, $P<0.0001$ ).

Finally, in groups 1 and 2, none of the patients who had their drains removed on POD3 developed pancreatic fistula.

TABLE 3. Comparative analysis between drain fluid amylase values and pancreatic fistula in the first and third evaluation.

\begin{tabular}{lccccc}
\hline Fistula & & & $\begin{array}{c}\text { POD 1 } \\
\text { values }\end{array}$ & $\begin{array}{c}\text { POD 3 } \\
\text { values }\end{array}$ & P value \\
\hline & N & Valid & 76 & 76 & \\
No & Missing & 0 & 0 & \\
& Median & & 706,5000 & 184,5000 & \\
& Minimum & & 2,00 & 3,00 & $<0.001$ \\
& Maximum & & 7333,00 & 2211,00 & \\
& & Valid & 26 & 26 & \\
Yes & Median & & 7608,0000 & 1885,0000 & \\
& Minimum & & 108,00 & 42,00 & $<0.001$ \\
& & & 0 & 0 & \\
& Maximum & & 30321,00 & 70558,00 & \\
\hline
\end{tabular}




\section{DISCUSSION}

Despite different descriptions regarding the anastomosis of the pancreatic remnant after PD, surgeons still do not have a proven superior technique ${ }^{(1)}$. Even in some high-volume centers, the pancreatic fistula rate is about $30 \%{ }^{(3)}$. Besides that, the presence of amylase on drain's fluid on POD1 (which does not represent PF by definition) may reflect the fact that pancreatic anastomosis is not tightly sealed, and somehow, small leaks will always occur, mainly on the first postoperative days. Actually, identifying those patients that have a high probability of clinically relevant PF development seems to be more important, and for this purpose, some strategies have been employed ${ }^{(8)}$.

Amylase obtained in drains content on the first postoperative day after pancreaticoduodenectomies has been the focus of many studies in the last few years. It has been correlated with the prediction of development and, moreover, with the severity of pancreatic fistula when it occurs ${ }^{(8,9)}$. In our study, we observed that patients who developed pancreatic fistula presented higher median POD1 DFA values $(7.608 \mathrm{U} / \mathrm{L} \times 706 \mathrm{U} / \mathrm{L}, P<0.001)$. In addition, in $\mathrm{G} 3$, the fistula-related mortality was $37.5 \%$, and patients who died had POD1 DFA values higher than the others in the same group $(17.777 \mathrm{U} / \mathrm{L} \times 6.002 \mathrm{U} / \mathrm{L}, P<0.0001)$.

Since 2007, after the publication of Molinari and colleagues ${ }^{(10)}$, the most used cutoff value to characterize low and high-risk patients for PF has been 5.000U/L. In that paper, it had the better sensitivity and area under the roc-curve. Thenceforward, randomized trials and meta-analyses have applied this value in different circumstances, aiming to find the answers to what patients had high probability of PF development, and also to guide decisions regarding the management of prophylactic abdominal drains.

Bassi and colls ${ }^{(9)}$ showed that patients that had POD1 DFA $<5.000 \mathrm{U} / \mathrm{L}$ and had drains removed on POD3 had less postoperative pancreatic fistulas than those that had drains in place for longer time. According to Verona and Pennsylvania protocols (two of the most notorious centers of pancreatic surgery in the world), if POD1 DFA is below this value and there is no clinical consideration or any sinister appearance of drain aspect, it should be removed earlier in the postoperative period, preferably on POD3, because of better outcomes, including less clinically relevant pancreatic fistulas ${ }^{(11)}$. We applied that recommendations in our last nine patients and, of note, we had no pancreatic fistula at all.

A recent meta-analyses reported that a value $>5.000 \mathrm{U} / \mathrm{L}$ on DFA on POD1 brought to patients a PF risk of about $70 \%$. However, when that value was $<100 \mathrm{U} / \mathrm{L}$, the $\mathrm{PF}$ risk dropped down to around $3 \%$ and, interestingly, this represents about $33 \%$ of patients $^{(12)}$. This way, a significant portion of patients may benefit from enhanced recovery protocols, like early enteral feeding and early discharge from hospital, possibly saving costs. In our study, we achieved similar outcomes using a cutoff point of $270 \mathrm{U} / \mathrm{L}$; only one $(3.3 \%)$ patient developed PF in that group, no one of them in the early drain removal group.

A recent paper published by Bertens and colleagues questioned the 5.000U/L value, defending $600 \mathrm{U} / \mathrm{L}$ as a more appropriate one ${ }^{(8)}$. In their study, $25 \%$ of patients that were classified as low risk by the POD1 DFA $5000 \mathrm{U} / \mathrm{L}$ cutoff in fact developed a clinically relevant postoperative pancreatic fistula, imputing a theoretical risk for those patients who would enter the protocol of early withdrawal of drains. However, data published by Bertens and colls did not address the real effect of early drain removal on that group in a prospective way (what was done by McMillan et al. $\left.{ }^{(11)}\right)$, making this conclusion inappropriate. It is possible that the pancreatic fistula rate could have been reduced if drains were removed earlier in the postoperative period, what was not mentioned in their work.

Our group reached similar unwise conclusions before being aware of McMillan's study. In a Letter to Editor published in $2017^{(13)}$, we questioned the pancreatic fistula rate reported by Fong et al. ${ }^{(14)}$. At that time, we were ongoing with our cohort group and we verified that some patients that had POD1 DFA up to 5.000 U/L, even reducing these values to a normal range on subsequent days, had developed late clinically relevant pancreatic fistulas. Again, according to McMillan's conclusions, keeping abdominal drains in that group could led to unfavorable outcomes.

In our cohort, using the cutoff point of $270 \mathrm{U} / \mathrm{L}$ led to a PF rate of $3.3 \%$, which might be reduced to zero if early withdrawn of drains was performed on that patient. Of mention, group 1 represented $29.4 \%$ of our entire population study, a significant rate of patients that could otherwise be managed in enhanced recovery protocols, what has been done in our latest ones. Maybe this group of patients represents the most appropriate for paradigm shifts related to drains management after PD, as the incidence of pancreatic fistula in this group is really low and probably surgeons would be more confortable to practice early drain removal in it. Those institutions that keep drains in place for longer times could start changing practice in POD1 low-amylase drain fluid values, achieving unquestionable and encouraging good outcomes.

Of mention, our mortality rate in this series is higher than that reported in high-volume centers. This probably reflects not only the possibility of reaching excellence when performing the same procedure again and again, but mostly the better perioperative care (including infrastructure, trained anesthesia personnel and intensive care unit team) available at these Institutions. Of note, a recent paper analyzing Brazilian patterns reported a $14.6 \%$ mortality rate after pancreatic surgery in Brazil $^{(6)}$, reaching $38 \%$ in some states.

\section{CONCLUSION}

Early drain fluid amylase value is useful to predict the occurrence of pancreatic fistula after pancreatoduodenectomies, in addition to correlate with the severity of this complication. It's a simple test that should be used routinely in institutions that perform this operation, since it can guide the postoperative care and identify those patients that must be managed under close observance.

\section{Authors' contribution}

Conception and design: Fontes PRO, Sampaio JA, Goldoni MB, Teixeira UF. Data collection: Teixeira UF, Goldoni MB, Rodrigues PD. Statistical analysis: Teixeira UF. Writing: Fontes PRO, Sampaio JA, Waechter FL, Teixeira UF. Critical revision: Teixeira UF, Rodrigues PD, Waechter FL. 
Teixeira UF, Rodrigues PD, Goldoni MB, Sampaio JA, Fontes PRO, Waechter FL. O valor da amilase, obtido precocemente nos drenos abdominais, é teste útil em prever a ocorrência de fístula pancreática após duodenopancreatectomia: lições aprendidas de um centro do Sul do Brasil. Arq Gastroenterol. 2018;55(2):160-3.

RESUMO - Contexto - A fístula pancreática representa a complicação mais temida após as duodenopancreatectomias, sendo a grande responsável pela elevada morbi-mortalidade após esta operação. Sua incidência permanece em torno de $10 \%$ a $30 \%$. Nos últimos anos, diversos trabalhos têm estudado o valor da amilase nos drenos abdominais, medido de forma precoce após o procedimento cirúrgico, como ferramenta útil para a identificação dos pacientes sob risco de desenvolver fístula pancreática. Objetivo - Avaliar o valor da amilase no fluido dos drenos abdominais, obtido precocemente no pós-operatório, como método para prever a ocorrência e severidade da fístula pancreática nos pacientes submetidos a duodenopancreatectomias. Métodos - Foram avaliados 102 pacientes prospectivos submetidos a duodenopancreatectomias no período de janeiro de 2013 a junho de 2017 . A dosagem da amilase nos drenos abdominais foi realizada nos dias 1, 3, 5 e 7 em todos os pacientes. Os pacientes foram divididos em três grupos conforme os resultados do $1^{\circ} \mathrm{PO}$ : valores $<270 \mathrm{U} / \mathrm{L}$ (grupo 1); entre 271 e $5.000 \mathrm{U} / \mathrm{L}$ (grupo 2); e valores $>5.000 \mathrm{U} / \mathrm{L}$ (grupo 3). Resultados - A incidência de fístula pancreática foi de $25,5 \%$, sendo $3,33 \%, 27,3 \%$ e $41,02 \%$ nos três grupos, respectivamente. Comparados ao grupo 1 , o risco de desenvolver fístula pancreática foi crescente com o aumento da amilase no $1^{\circ} \mathrm{PO}$. Os valores das amilases no $1^{\circ} \mathrm{PO}$ e $3^{\circ} \mathrm{PO}$ dos pacientes com fístula pancreática foram maiores do que nos pacientes sem essa complicação $(P<0,001)$. Além disso, no grupo 3,37,5\% dos pacientes com fístula pancreática evoluíram para óbito $(P<0,001)$. Por fim, neste grupo, os pacientes que evoluíram para óbito tiveram valores de amilase no $1^{\circ} \mathrm{PO}$ significativamente maiores do que os demais pacientes $(P<0,001)$. Conclusão - $\mathrm{O}$ valor da amilase, medido de forma precoce nos drenos abdominais no pós-operatório de duodenopancreatectomias, é teste útil para estratificar pacientes em relação ao risco de apresentar fístula pancreática, além de se correlacionar com a severidade dessa complicação.

DESCRITORES - Pancreaticoduodenectomia. Amilases. Fístula pancreática.

\section{REFERENCES}

1. Fontes PR, Waechter FL, Nectoux M, Sampaio JA, Teixeira UF, Pereira-Lima L. Low mortality rate in 97 consecutive pancreaticoduodenectomies: the experience of a group. Arq Gastroenterol. 2014;51:29-33.

2. McMillan MT, Vollmer CM Jr, Asbun HJ, Ball CG, Bassi C, Beane JD, et al. The characterization and prediction of ISGPF grade $\mathrm{C}$ fistulas following pancreatoduodenectomy. J Gastrointest Surg. 2016;20:262-76.

3. McMillan MT, Soi S, Asbun HJ, Ball CG, Bassi C, Beane JD, et al. Risk-adjusted outcomes of clinically relevant pancreatic fistula following pancreatoduodenectomy: a model for performance evaluation. Ann Surg. 2016;264:344-52.

4. Israel JS, Rettammel RJ, Leverson GE, Hanks LR, Cho CS, Winslow ER, et al. Does postoperative drain amylase predict pancreatic fistula after pancreatectomy? J Am Coll Surg. 2014;218:978-87.

5. Lee CW, Pitt HA, Riall TS, Ronnekleiv-Kelly SS, Israel JS, Leverson GE, et al. Low drain fluid amylase predicts absence of pancreatic fistula following pancreatectomy. J Gastrointest Surg. 2014;18:1902-10.

6. Dos Santos LV, Lessa MAO, Lima JPSN, Haaland B, Lopes GL. Curative-Intent Surgery for Pancreatic Tumors: A Review of Procedures From the Brazilian National Health System. J Glob Oncol. 2016;3:37-42.

7. Bassi C, Marchegiani G, Dervenis C, Sarr M, Abu Hilal M, Adham M, et al. The 2016 update of the International Study Group (ISGPS) definition and grading of postoperative pancreatic fistula: 11 Years After. Surgery. 2017;161:584-91.

8. Bertens KA, Crown A, Clanton J, Alemi F1, Alseidi AA1, Biehl T, et all. What is a better predictor of clinically relevant postoperative pancreatic fistula (CR-POPF) following pancreaticoduodenectomy (PD): postoperative day one drain amylase (POD1DA) or the fistula risk score (FRS)? HPB (Oxford). 2017;19:75-81.
9. Bassi C, Molinari E, Malleo G, Crippa S, Butturini G, Salvia R, et al. Early versus late drain removal after standard pancreatic resections: results of a prospective randomized trial. Ann Surg. 2010;252:207-14.

10. Molinari E, Bassi C, Salvia R, Butturini G, Crippa S, Talamini G, et al. Amylase value in drains after pancreatic resection as a predictive factor of postoperative pancreatic fistula: results of a prospective study in 137 patients. Ann Surg. 2007;246:281-7.

11. McMillan MT, Malleo G, Bassi C, Allegrini V, Casetti L, Drebin JA, et al. Multicenter, Prospective Trial of Selective Drain Management for Pancreatoduodenectomy Using Risk Stratification. Ann Surg. 2017;265:1209-18.

12. Giglio MC, Spalding DR, Giakoustidis A, Zarzavadjian Le Bian A, Jiao LR, Habib NA, Pai M. Meta-analysis of drain amylase content on postoperative day 1 as a predictor of pancreatic fistula following pancreatic resection. Br J Surg. 2016;103:328-36.

13. Teixeira UF, Goldoni MB, Waechter FL. Early Drain Amylase Value Predicts the Occurrence of Pancreatic Fistula After Pancreaticoduodenectomy. Ann Surg. 2017;266:e79-e80.

14. Fong ZV, Correa-Gallego C, Ferrone CR, Veillette GR, Warshaw AL, Lillemoe $\mathrm{KD}$, et al. Early drain removal-the middle ground between the drain versus no drain debate in patients undergoing pancreaticoduodenectomy. A prospective validation study. Ann Surg 2015;262:378-83. 